\title{
Aktywność neotektoniczna Pasma Lubania (Gorce) na podstawie analizy parametrów morfometrycznych
}

\author{
Krzysztof Buczek ${ }^{1}$, Marek Górnik ${ }^{1}$
}

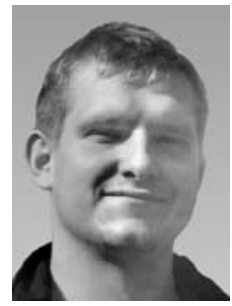

K. Buczek

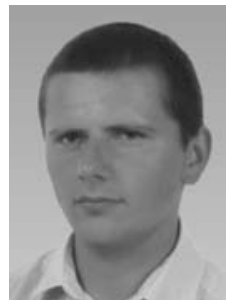

M. Górnik

Neotectonic activity of Lubań Range (Gorce Mts.) based on morphometric indices. Prz. Geol., 67: 270-278; doi: 10.7306/2019.24

A b s tra $\mathrm{c}$. The aim of this paper is to use a relative tectonic index (Iat) in order to evaluate tectonic activity in the intermediate mountain area of the Luban Range. To estimate the tectonic activity in the study area, we analyzed 6 DEM derived geomorphic indices for 66 basins: the stream-gradient index $(S L)$, asymmetry factor $(A f)$, basin shape ratio $\left(B_{s}\right)$, hypsometric integral $(H i)$, valley floor width-valley height ratio $\left(V_{f}\right)$ and mountain-front sinuosity $\left(S_{m}\right)$. These parameters were combined to obtain the relative tectonic activity index (Iat). According to Iat values, ca. $25 \%$ of the Luban' Range was classified as areas of relatively high tectonic activity and ca. $72 \%$ as moderately tectonically active. The Iat values suggest a higher relative tectonic activity in the western part of the range, since some morphometric indices, like HI and SL, indicate a higher rate of tectonic uplift along the Dunajec Fault and normal faults on the northern slopes of the Luban Range. The rate of the tectonic uplift obtained from the Iat values is similar to that derived from river incision. Morphometric analysis as well as field evidence of active tectonics, such as triangular facets, suggest a high rate of tectonic uplift along the northern margins of the range and probably along the eastern slopes of the Luban Range. The high relative tectonic activity on the southern slopes in the western part of the Luban' Range is probably related to active subsidence of the Nowy Targ Basin.

Keywords: index of relative tectonic activity, Carpathians, Lubań Range, geomorphic indices, tectonic uplift

Szybki rozwój technik opierających się na analizach numerycznych modeli terenu (NMT) z użyciem narzędzi GIS spowodował, że geomorfologia tektoniczna stała się popularnym kierunkiem badań geomorfologicznych, o czym świadczy znaczna liczba zagranicznych publikacji dotyczących tej tematyki (Strahler, 1954; Bull, McFadden, 1977; Burbank, Anderson, 2011; Alipoor i in., 2011; Bahrami, 2013; Bagha i in., 2014; Chang i in., 2015; Ntokos i in., 2016). Zastosowanie numerycznych modeli wysokościowych stworzyło warunki do szybszej analizy parametrów morfometrycznych znacznie większych obszarów (Azañón i in., 2012). Narzędzia GIS umożliwiły m.in. automatyczne odwzorowanie sieci drenażu czy też stosowanie specjalistycznych analiz, które przy użyciu tradycyjnych map topograficznych nie były osiagalne.

Do oceny tektonicznej aktywności danego obszaru wykorzystuje się różne wskaźniki morfometryczne, na podstawie których jest obliczany jeden, syntetyczny wskaźnik aktywności tektonicznej. Według Różyckiej (2015) zastosowanie kilku wskaźników morfometrycznych należących do różnych kategorii ułatwia odróżnienie zmian morfologii terenu wywołanych odpornością skał podłoża od tych powodowanych aktywnością tektoniczną. Jednym z syntetycznych wskaźników morfometrycznych, najczęściej stosownym do tego celu za granica, jest wskaźnik względnej aktywności tektonicznej (Iat - Index of Relative Active Tectonic), zaproponowany przez El Hamdouniego $\mathrm{i}$ in. (2008). Dotychczas wskaźnik Iat stosowano do badania takich obszarów aktywnych tektonicznie, jak m.in.: góry Sierra Nevada (El Hamdouni, 2008), masyw Elbursu (Bagha i in., 2014; Alaei i in., 2017), góry Zagros (Dehbozorgi i in., 2010; Arian, Aram, 2014; Eshani, Arian, 2015) czy Wyżyna Tybetańska (Chang i in., 2015). Wyniki tych badań wskazują na znaczną użyteczność wskaźnika Iat do oceny aktywności tektonicznej zarówno pojedynczych krawędzi, jak i całych masywów górskich. Wskaźnik Iat nie był do tej pory stosowany $\mathrm{w}$ górach średnich. Na terytorium Polski zastosowanie podobnych syntetycznych wskaźników aktywności tektonicznej ograniczało się do obszaru Roztocza i Wzniesień Urzędowskich (Brzezińska-Wójcik, 2013; Chabudziński, Brzezińska-Wójcik, 2013).

Celem pracy było zastosowanie syntetycznego wskaźnika względnej aktywności tektonicznej (Iat) do określenia aktywności tektonicznej w wybranym obszarze polskich Karpat.

\section{OBSZAR BADAŃ}

Do badań wytypowano Pasmo Lubania, które leży w południowo-wschodniej części Gorców, stanowiących część Beskidów Zachodnich (Kondracki, 2000) i podlega czwartorzędowym ruchom wypiętrzającym (Zuchiewicz, 1978, 1984; Forma, Zuchiewicz, 2002; Olszak, 2009). Pasmo to ma długość ok. $22 \mathrm{~km}$, zajmuje obszar ok. $122 \mathrm{~km}^{2}$ i jest wyraźnie wyodrębnione. Od południa graniczy ono z Kotliną Orawsko-Nowotarską oraz Pieninami, a wzdłuż przełomowej doliny Dunajca z Beskidem Sądeckim. Od pozostałej części Gorców jest oddzielone doliną Ochotnicy oraz Potoku Knurowskiego. W jego rzeźbie dominują strome stoki oraz głębokie wciosy o przebiegu radialnym. Główny grzbiet ma przebieg równoleżnikowy z niewielkimi, kopulastymi kulminacjami (m.in. Runek 1005 m n.p.m) oraz płytkimi przełęczami. Wysokość pasma stopniowo zwiększa się z zachodu na wschód, osiągając maksimum na podwójnym wierzchołku Lubania (1210 m n.p.m. szczyt zachodni, 1212 m n.p.m. - wschodni). Największe deniwelacje w tym paśmie $(>400 \mathrm{~m})$ występują na wschodnich stokach Lubania - w strefie przełomu Dunajca

\footnotetext{
${ }^{1}$ Instytut Ochrony Przyrody Polskiej Akademii Nauk, al. Adama Mickiewicza 33, 31-120 Kraków; buczek@iop.krakow.pl
} 
przez Beskidy (Zuchiewicz, 2010). W głębokich lejach źródłowych występują liczne, niekiedy bardzo rozległe, obszary osuwiskowe (Bucała i in., 2014; Płaczkowska, 2014; Buczek, 2016).

Masyw Lubania składa się ze skał fliszu karpackiego podjednostki krynickiej płaszczowiny magurskiej (Watycha, 1972; Burtan i in., 1976; Paul, 1978; Kulka i in., 1985). Najstarszymi skałami, odsłaniającymi się na badanym terenie, są cienkoławicowe piaskowce i łupki należące do formacji szczawnickiej (ryc. 1), których wiek określono na środkowy paleocen-dolny eocen (Kulka in., 1991). Skały te, wraz z ogniwem z Życzanowa (stropowa część formacji szczawnickiej), występują w dolnych partiach południowych, wschodnich oraz częściowo północnych stoków obszaru badań (Paul, 1978, 1980; Kulka in., 1985, 1991).

Na większości obszaru badań odsłaniają się skały formacji magurskiej (dolny eocen-oligocen). Cechą charakterystyczną tej formacji jest dominacja gruboławicowych piaskowców o litotypie piaskowców magurskich (Watycha, 1972, 1976; Burtan i in., 1976, 1978; Paul, 1978, 1980; Kulka i in., 1985, 1991). W Paśmie Lubania formacja magurska dzieli się na trzy ogniwa - piaskowców z Piwnicznej, warstw z Kowańca oraz piaskowców z Popradu (Watycha, 1972, 1976; Burtan i in., 1976, 1978; Paul, 1978, 1980; Kulka i in., 1985, 1991). Ogniwo piaskowców z Piwnicznej (dolny-środkowy eocen) w większości składa się z grubo i bardzo gruboławicowych piaskowców i zlepieńców, rozdzielonych przez pakiety cienkoławicowych piaskowców, mułowców i łupków z przewarstwieniami margli (Kulka i in., 1991). Warstwy z Kowańca, reprezentowane głównie przez cienkoławicowe piaskowce i mułowce ze znacznym udziałem łupków, występują w formie kilku pasów na południowych oraz północnych stokach tego masywu (ryc. 1). Środkową, najwyższą, część pasma stanowią odporne na wietrzenie, gruboławicowe piaskowce oraz zlepieńce ogniwa piaskowców z Popradu (Kulka i in., 1991).

Pasmo Lubania, szczególnie w kontakcie z Pienińskim Pasem Skałkowym, jest silnie sfałdowane oraz poprzecinane licznymi uskokami (Kulka i in., 1985, 1991). Skały formacji magurskiej tworzą największą strukturę tektoniczną na obszarze badań - synklinę Lubania, której oś przebiega zgodnie z głównym grzbietem pasma. Od wschodu synkli-

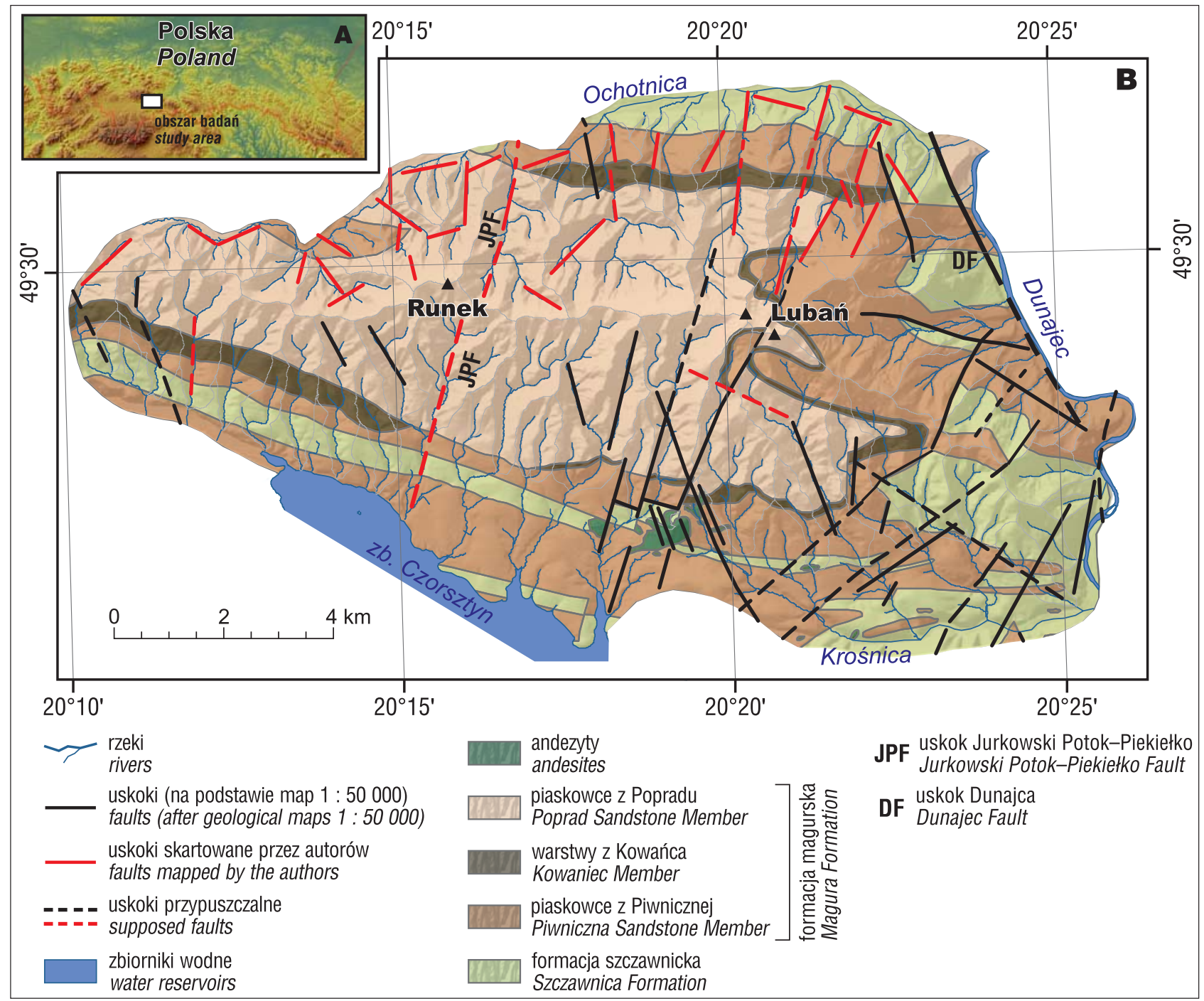

Ryc. 1. Lokalizacja obszaru badań (A) oraz uproszczona mapa geologiczna Pasma Lubania (B) (wg Watychy, 1972, Burtana i in. 1976; Paula, 1978; Kulki i in., 1985; tektonika uzupełniona przez autorów)

Fig. 1. Location of the study area (A) and simplified geological sketch map of the Lubań Range (B) (after Watycha, 1972; Burtan et al., 1976; Paul, 1978; Kulka et al., 1985; tectonic sketch map supplemented by the authors) 
na ta jest obcięta przez uskok Dunajca (Żytko, 1963). Osie wszystkich synklin i antyklin na obszarze badań mają przebieg zbliżony do równoleżnikowego. Struktury te są rozcięte przez liczne uskoki, przeważnie zorientowane SSE-NNW i SSW-NNE (Watycha, 1972, 1976; Burtan i in., 1976, 1978; Paul, 1978, 1980; Kulka i in., 1985, 1991). Jeden z tych uskoków wyraźnie zaznacza się na mapie cieniowanej rzeźby terenu, dzieląc Pasmo Lubania z SSW na NNE. Uskok ten został przez autorów artykułu rozpoznany w niewielkim odsłonięciu w dolinie Potoku Jurkowskiego i w dalszej części artykułu jest nazwany uskokiem Jurkowski Potok-Piekiełko. Rysy ślizgowe oraz zadziory, widoczne na powierzchni luster tektonicznych, umożliwiły identyfikację lewoprzesuwczego typu przemieszczeń $\left(132-148 / 54-60^{\circ}\right)$ oraz prawdopodobnie reaktywację tego uskoku przesuwczego jako uskoku normalnego (122-130/60-68 ). Reaktywacja uskoków przesuwczych była w Karpatach zewnętrznych zjawiskiem powszechnym (Książkiewicz, 1972; Mastella, 1988; Konon, 2001). Pasmo Lubania jest obramowane przez różnego typu trójkątne oraz trapezoidalne lica, charakterystyczne dla uskoków normalnych, reaktywowanych w trakcie dźwigania tektonicznego (Migoń, 2006).

Według Zuchiewicza (1984) Pasmo Lubania jest częścią najsilniej podnoszącej się struktury neotektonicznej w polskich Karpatach zewnętrznych. Rozcinający tę strukturę Dunajec utworzył głęboki przełom z zachowanymi poziomami 12 tarasów skalno-osadowych, z których najwyższy znajduje się ok. $160 \mathrm{~m}$ powyżej współczesnego koryta Dunajca (Zuchiewicz, 1984). Na podstawie szacowanego klimatostratygraficznie wieku tarasów Zuchiewicz $(1984,2011)$ określił tempo podnoszenia przełomu Dunajca na $0,12-0,24 \mathrm{~mm} /$ rok (interglacjał eemski-holocen) oraz ok. $1 \mathrm{~mm} /$ rok w trakcie holocenu. Wyniki badań poziomów tarasów dwóch lewobrzeżnych dopływów Dunajca - Ochotnicy i Kamienicy - świadczą o zróżnicowanym tempie wcinania się tych cieków w plejstocenie i holocenie (Olszak, 2009). Różnice te, według autorów artykułu, wskazują prawdopodobnie na neotektoniczną aktywność głębokich stref uskokowych związanych ze strefą nasunięcia podjednostki krynickiej na bystrzycką (Olszak, 2009). Datowania poziomów tarasów metodą optycznie stymulowanej luminescencji (OSL) pozwoliły na weryfikację dotychczas szacowanego wieku tarasów w przełomie Dunajca oraz w dolinie Ochotnicy (Olszak, Adamiec, 2016). Wyniki tych badań wskazały na znacznie młodszy wiek poziomów tarasowych oraz większe tempo wypiętrzania obszaru, wynoszące ok. $0,6 \mathrm{~mm} / \mathrm{r}$ w ciagu ostatnich 150 tys. lat (Olszak, Adamiec, 2016). Wykazano również zróżnicowane tempo wypiętrzania tektonicznego w poszczególnych częściach przełomu Dunajca (Olszak, 2017).

\section{METODYKA}

Do scharakteryzowania tektonicznej aktywności badanego obszaru wykorzystano 6 cząstkowych wskaźników morfometrycznych: asymetrii zlewni Af, kształtu zlewni $\mathrm{B}_{\mathrm{s}}$, długości-spadku cieku SL, całki hipsometrycznej Hi, wskaźnika szerokości dna-wysokości zboczy doliny $\mathrm{V}_{\mathrm{f}}$ oraz wskaźnika krętości frontu górskiego $\mathrm{S}_{\mathrm{mf}}$, które posłużyły do obliczenia syntetycznego wskaźnika względ- nej aktywności tektonicznej Iat według metodyki zaproponowanej przez El Hamdouniego i in. (2008). Prace rozpoczęto od wytyczenia na podstawie NMT przebiegu frontów górskich okalających Pasmo Lubania (Bull, McFadden, 1977). Przebieg ten w znacznym stopniu dowiązuje do zespołów lic progów uskokowych (ryc. 3). Obszary położone poniżej wytyczonych frontów górskich nie zostały włączone do analizy. Do badań wybrano 66 zlewni o powierzchni większej od $0,1 \mathrm{~km}^{2}$, rozciętych przez wytyczone fronty górskie. Łączna powierzchnia badanych zlewni wynosiła $88,7 \mathrm{~km}^{2}$, co stanowi ok. $73 \%$ powierzchni Pasma Lubania. Analizę parametrów morfometrycznych wybranych zlewni przeprowadzono na podstawie NMT o rozdzielczości $1 \mathrm{~m}$, wygenerowanego z danych LiDAR.

Wskaźnik asymetrii zlewni (Af - asymmetry factor) przedstawiający stosunek powierzchni prawej strony zlewni $\left(\mathrm{A}_{\mathrm{r}}\right)$ do całkowitej powierzchni zlewni $\left(\mathrm{A}_{\mathrm{t}}\right)$ wyraża się wzorem (Hare, Gardner, 1985):

$$
A f=\left(\frac{A_{r}}{A_{t}}\right) \times 100
$$

Wskaźnik Af jest czuły na tektoniczne przechylanie obszaru w kierunku prostopadłym do głównej linii drenażu (Hare, Gardner, 1985). Wartości wskaźnika zostały przyporządkowane do trzech klas aktywności tektonicznej określonych przez El Hamdouniego i in. (2008):

$\square$ klasa I - Af $\geq 68$ oraz Af $<21$ (aktywność wysoka);

$\square$ klasa II $-55 \leq$ Af $<68$ i $21 \leq$ Af $<42$ (umiarkowana);

$\square$ klasa III $-42 \leq$ Af $<55$ (słaba).

Wartości Af zbliżone do 50 (klasa III) wskazują na zlewnie symetryczne, podczas gdy wartości znacząco większe lub mniejsze od 50 (klasy I i II) wyrażają odpowiednio wzrost udziału powierzchni prawej lub lewej strony zlewni.

Planimetryczny wskaźnik kształtu zlewni $\left(\mathrm{B}_{\mathrm{s}}-\right.$ basin shape ratio) należy do grupy wskaźników opisujących kształt zlewni (Ramírez-Herrera, 1998; Różycka, 2015). Wyraża się on wzorem:

$$
B_{s}=\frac{B_{1}}{B_{w}}
$$

gdzie:

$\mathrm{B}_{1}$ - maksymalna długość zlewni, mierzona od jej zamknięcia do najbardziej oddalonego punktu na dziale wodnym $\mathrm{B}_{\mathrm{w}}$ - maksymalna szerokość zlewni

Wysokie wartości wskaźnika $\mathrm{B}_{\mathrm{s}}$ oznaczają zlewnie silniej wydłużone, uznawane dotychczas za relatywnie bardziej aktywne tektonicznie (Ramírez-Herrera, 1998; El Hamdouni i in., 2008; Forma, Zuchiewicz, 2002). Wartości wskaźnika $\mathrm{B}_{\mathrm{s}}$ przyporządkowano do trzech klas aktywności tektonicznej (wg El Hamdouniego i in., 2008):

$\square$ klasa $\mathrm{I}-\mathrm{B}_{\mathrm{s}} \geq 4$;

$\square$ klasa II $-3>\mathrm{B}_{\mathrm{s}}<4$;

$\square$ klasa III $-\mathrm{B}_{\mathrm{s}} \leq 3$.

W metodzie zaproponowanej przez El Hamdouniego $\mathrm{i}$ in. (2008) do określenia zmienności spadku cieków wykorzystano wskaźnik długości-spadku cieku (SL - stream length-gradient index), wyrażony wzorem (Hack, 1973): 


$$
S L=\left(\frac{\Delta h}{\Delta l}\right) l
$$

gdzie:

$\Delta h$ - różnica wysokości na badanym odcinku

$\Delta l$ - długość odcinka

1 - odległość pomiędzy źródłem cieku, a punktem wyznaczającym środek badanego odcinka.

Profile podłużne cieków stanowią bardzo czuły indykator zmian nachylenia powierzchni wywołanych aktywnością tektoniczną (Burbank, Anderson, 2011). Wysokie wartości wskaźnika SL mogą występować zarówno na obszarach wypiętrzanych, jak i zbudowanych ze skał bardziej odpornych na erozję, a anomalnie niskie wskazują na rozwój doliny zorientowanej równolegle do uskoku przesuwczego (Keller, Pinter, 2002). Uzyskane wartości wskaźnika Sl przyporządkowano do trzech klas aktywności tektonicznej wg El Hamdouniego i in. (2008):

$\square$ klasa I - SL > 490;

$\square$ klasa II $-239>$ SL $<490$;

klasa III - SL $<239$.

Całka hipsometryczna (Hi - hypsometric integral) jest wskaźnikiem morfometrycznym opisującym zróżnicowanie wysokości na badanym obszarze (Strahler, 1952). Wskaźnik ten wyraża się wzorem:

$$
H i=\frac{\left(H_{\text {mean }}-H_{\text {min }}\right)}{\left(H_{\max }-H_{\min }\right)}
$$

gdzie:

Hi - wskaźnik bezwymiarowy, przyjmujący wartości od 0 do 1

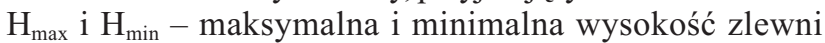
[m n.p.m.]

$\mathrm{H}_{\text {mean }}$ - średnia wysokość zlewni [m n.p.m.]

Wysokie wartości wskaźnika Hi wskazują na większy udział w zlewni powierzchni usytuowanych na relatywnie dużej wysokości, co jest łączone z młodszym etapem rozwoju rzeźby (Strahler, 1952) i większą aktywnością tektoniczną (El Hamdouni i in., 2008). Obliczone wartości wskaźnika Hi przyporządkowano do trzech klas aktywności tektonicznej, określonych przez El Hamdouniego i in. (2008):

$\square$ klasa I $-\mathrm{Hi}>0,5$;

$\square$ klasa II $-0,5>\mathrm{Hi}<0,4$;

$\square$ klasa III $-\mathrm{Hi}<0,4$.

Wskaźnik szerokości dna-wysokości zboczy doliny $\left(\mathrm{V}_{\mathrm{f}}\right.$ - ratio of valley floor width to valley height) służy do rozróżniania dolin v-kształtnych, którym odpowiadają niskie wartości wskaźnika $\mathrm{V}_{\mathrm{f}}$, od dolin szerokodennych, charakteryzujących się wysokimi wartościami tego wskaźnika (Bull, McFadden, 1977). Niskie wartości wskaźnika $\mathrm{V}_{\mathrm{f}}$ mogą się też wiązać z obszarami aktywnie wypiętrzanymi (Keller, Pinter, 1996). Wskaźnik ten został opisany wzorem (Bull, McFadden, 1977):

$$
V_{f}=\frac{2 V_{f w}}{\left[\left(E_{l d}-E_{s c}\right)+\left(E_{r d}-E_{s c}\right)\right]}
$$

gdzie:

$\mathrm{V}_{\mathrm{fw}}-$ szerokość doliny $[\mathrm{m}]$
$\mathrm{E}_{\mathrm{ld}} \mathrm{i} \mathrm{E}_{\mathrm{rd}}$-wysokość lewego i prawego wododziału [mn.p.m.] $\mathrm{E}_{\mathrm{sc}}-$ wysokość dna doliny [m n.p.m.]

Wartości wskaźnika $V_{\mathrm{f}}$ przyporządkowano następnie do trzech klas aktywności tektonicznej wg El Hamdouniego i in. (2008):

$\square$ klasa $\mathrm{I}-\mathrm{V}_{\mathrm{f}} \leq 0,5$;

$\square$ klasa II $-0,5 \leq \mathrm{V}_{\mathrm{f}}<1$;

$\square$ klasa III $-\mathrm{V}_{\mathrm{f}} \geq 1$.

Wskaźnik krętości frontu górskiego $\left(\mathrm{S}_{\mathrm{mf}}-\right.$ index of mountain sinuosity) służy do oceny względnej aktywności tektonicznej wzdłuż frontów górskich (Bull, McFadden, 1977; Bull, 1978; Silva i in., 2003; El Hamdouni i in., 2008). Określa on stan równowagi pomiędzy wypiętrzaniem obszaru, które prowadzi do zachowania prostoliniowego przebiegu frontu górskiego a erozją cieków, skutkującą wzrostem krętości frontu. Wskaźnik ten wyraża się wzorem (Bull, McFadden, 1977):

$$
S_{m f}=\frac{L_{m f}}{L_{s}}
$$

gdzie:

$\mathrm{L}_{\mathrm{mf}}$ - całkowita długość frontu [m], mierzona wzdłuż wyraźnego załomu stoku

$\mathrm{L}_{\mathrm{s}}$ - długość linii prostej, łączącej dwa najbardziej oddalone punkty frontu górskiego.

Wyliczone wartości tego wskaźnika przyporządkowano do trzech klas aktywności tektonicznej wyznaczonych przez El Hamdouniego i in. (2008):

$\square$ klasa $\mathrm{I}-\mathrm{S}_{\mathrm{mf}}<1,1$;

$\square$ klasa II $-1,1 \leq \mathrm{S}_{\mathrm{mf}}<1,5$;

$\square$ klasa III $-\mathrm{S}_{\mathrm{mf}} \geq 1,5$.

Klasom tektonicznej aktywności zlewni, określonym na podstawie wskaźników cząstkowych, przypisano punkty - odpowiednio klasa $1=1$ pkt., klasa $2=2$ pkt., klasa $3=$ 3 pkt. Wskaźnik Iat tektonicznej aktywności wszystkich zlewni obliczono jako sumę punków każdego z sześciu wskaźników, podzieloną przez liczbę tych wskaźników. Obliczone średnie wartości zostały zaklasyfikowane do trzech klas względnej aktywności tektonicznej (Iat), zaproponowanych przez El Hamdouniego i in. (2008):

$\square$ klasa I $-1,5<$ Iat $<2$ (aktywność tekt. wysoka);

$\square$ klasa II $-2<$ Iat $<2,5$ (umiarkowana);

$\square$ klasa III $-2,5<$ Iat (niska).

Według El Hamdouniego i in. (2008) obszary aktywne tektonicznie (klasa I Iat) charakteryzują się dźwiganiem obszaru w tempie $>0,4-0,5 \mathrm{~mm} / \mathrm{rok}$, umiarkowanie aktywne tempem $0,5-0,05 \mathrm{~mm} /$ rok (klasa II Iat), a słabo aktywne $<0,05 \mathrm{~mm} /$ rok (klasa III Iat).

\section{WYNIKI}

\section{Wskaźnik krętości frontu masywu górskiego $S_{\mathrm{mf}}$}

Wskaźnik $\mathrm{S}_{\mathrm{mf}}$ obliczono dla ośmiu frontów górskich okalających Pasmo Lubania (ryc. 2A). Stosunkowo prostolinijny przebieg siedmiu $\mathrm{z}$ nich $\left(\mathrm{S}_{\mathrm{mf}}\right.$ od 1,02 do 1,08$)$ wskazuje na dużą aktywność tektoniczną badanego obszaru (Bull, McFadden, 1977; Bull, 1978; Silva i in., 2003; El Hamdouni i in., 2008). Natomiast front górski w przełomie 
Dunajca ma przebieg łukowaty (F5 na ryc. 2A) i w związku z tym został zaklasyfikowany jako umiarkowanie aktywny tektonicznie.

\section{Wskaźnik asymetrii zlewni Af}

Na obszarze Pasma Lubania wskaźnik asymetrii zlewni Af osiaga wartości od 17,1 do 69,2 (ryc. 2E). Tylko ok. 2,6\% badanego obszaru cechuje się silną asymetrią zlewni, charakterystyczną dla obszarów aktywnych tektonicznie (klasa I). Zlewnie należące do klasy I są zlokalizowane wzdłuż północnej krawędzi Pasma Lubania. Około 64\% powierzchni Pasma Lubania zaklasyfikowano do II klasy Af. Zlewnie należące do III klasy Af, symetryczne lub w niewielkim stopniu asymetryczne, występują w rozproszeniu wzdłuż północnej oraz południowej krawędzi pasma, a także tworzą wyraźną grupę obejmującą wschodnie i północne stoki Lubania (w strefie przełomowej doliny Dunajca) oraz w pobliżu ujścia Ochotnicy do Dunajca.

Analiza przestrzennego rozmieszczenia wskaźnika asymetrii zlewni nie sugeruje wyraźnych, wielkoskalowych tendencji pochylania tektonicznego w obrębie pasma. Niejednokrotnie sąsiadujące ze sobą zlewnie charakteryzują się przeciwnymi kierunkami asymetrii, prawdopodobnie uwarunkowanymi strukturalnie lub litologicznie. Jedynie zlewnie dopływów Krośnicy na południowych stokach Pasma Lubania charakteryzują się wyraźnie mniejszym udziałem powierzchni orograficznie prawej części zlewni. Prawdopodobnie jest to związane $\mathrm{z}$ pochyleniem tej części pasma w kierunku zachodnim na skutek wypiętrzania wschodnich stoków Lubania.

\section{Planimetryczny wskaźnik kształtu zlewni $B_{s}$}

Planimetryczny wskaźnik kształtu zlewni $\mathrm{B}_{\mathrm{s}}$ przyjmuje na badanym obszarze wartości od 1,25 do 4,71 (ryc. 2B). Tylko ok. $6 \%$ obszaru badań zaklasyfikowano do I klasy aktywności tektonicznej - są to najsilniej wydłużone zlewnie na w okolicy Runka południowych stokach Pasma Lubania. Do klasy II należy ok. 20\% powierzchni badanego pasma, w tym przede wszystkim zlewnie odwadniające północne stoki szczytowej kopuły Lubania (1211 m n.p.m.), wzdłuż uskoku normalnego obramowującego dolinę Ochotnicy, co może wskazywać na umiarkowaną aktywność tektoniczną. Niskimi wartościami wskaźnika $\mathrm{B}_{\mathrm{s}}$ charakteryzuje się ponad $74 \%$ powierzchni Pasma Lubania (klasa III).

\section{Wskaźnik długości-spadku cieku SL}

Średnie wartości wskaźnika SL obliczone dla zlewni Pasma Lubania wynosiły od 60 do 271 (ryc. 2C). Stosując kryteria klasyfikacji za El Hamdounim i in. (2008) żadnej ze zlewni nie zaklasyfikowano do I klasy aktywności tektonicznej. Do II klasy aktywności należą zlewnie tylko czterech potoków odwadniających wierzchołek Lubania od północy i wschodu (ok. 12\% powierzchni obszaru badań). Większość obszaru zaklasyfikowano jako słabo aktywną tektonicznie (klasa III), jednak stwierdzono wyraźny wzrost średnich wartości wskaźnika SL, postępujący z zachodu na wschód Pasma Lubania (ryc. 2C). Wartości wskaźnika SL, w przeciwieństwie do wskaźnika $\mathrm{B}_{\mathrm{s}}$, moga wskazywać na silniejsze wypiętrzanie tektoniczne wzdłuż wschodniej i północnej krawędzi Pasma Lubania. Wypiętrzanie to może następować wzdłuż uskoku Dunajca oraz uskoków normalnych obramowujących dolinę Ochotnicy. Wyraźna zmiana wartości wskaźnika jest widoczna na linii uskoku Jurkowski Potok-Piekiełko (ryc. 2).

\section{Całka hipsometryczna Hi}

Wartości całki hipsometrycznej $\mathrm{Hi}$, wyliczone dla badanych zlewni, wynosiły od 0,35 do 0,62 (ryc. 2D). Większość obszaru badań (61\%) zaklasyfikowano do II klasy aktywności tektonicznej. Zlewnie w zachodniej części Pasma Lubania (na zachód od uskoku Jurkowski Potok-Piekiełko) oraz wzdłuż przełomowej doliny Dunajca (ryc. 2D) należą do klasy I $(\mathrm{Hi}>0,5)$ i znajdują się w młodocianym stadium rozwoju rzeźby (Strahler, 1952). Zajmują one ok. 33\% Pasma Lubania. Zlewnie położone na południowych stokach Lubania, na wschód od linii uskoku Jurkowski Potok-Piekiełko, charakteryzują się najniższymi wartościami Hi (klasa III). Zlewnie należące do III klasy zajmują ok. $6 \%$ obszaru badań.

\section{Wskaźnik szerokości dna-wysokości zboczy doliny $V_{f}$}

$\mathrm{Na}$ analizowanym obszarze Pasma Lubania wartości wskaźnika szerokości dna-wysokości zboczy doliny $\mathrm{V}_{\mathrm{f}}$ zmieniają się od 0,13 w zlewniach na wschodnich stokach Lubania do 1,96 w zlewniach na stokach południowych (ryc. 2E). Małe wartości wskaźnika $\mathrm{V}_{\mathrm{f}}$, świadczące o dużej aktywności tektonicznej (klasa I), charakteryzują ok. 45\% obszaru badań. Zlewnie należące do I klasy aktywności tektonicznej występują w trzech obszarach: w zachodniej części Pasma Lubania, na zachód od uskoku Jurkowski Potok-Piekiełko oraz w dużym rozproszeniu wzdłuż południowych i północnych krawędzi wschodniej części obszaru badań. Najszerszymi dnami dolin (klasa III) charakteryzują się głównie zlewnie położone na południowych stokach Lubania (ok. 14\% obszaru badań).

\section{Wskaźnik względnej aktywności tektonicznej Iat}

Na podstawie wartości wskaźnika względnej aktywności tektonicznej Iat większość badanych zlewni (ok. 72\% obszaru badań) zaklasyfikowano do umiarkowanej klasy aktywności tektonicznej (ryc. 3). Zlewnie o dużej aktywności tektonicznej $(1,5<$ Iat $<2,0)$ obejmują $25 \%$ powierzchni obszaru badań i są zlokalizowane głównie w zachodniej części Pasma Lubania, na zachód od uskoku Jurkowski Potok-Piekiełko, oraz w rozproszeniu wzdłuż północnej i wschodniej krawędzi pasma (ryc. 3). Jedynie cztery zlewnie znajdujące się w różnych częściach pasma zaklasyfikowano do klasy niskiej aktywności tektonicznej.

\section{DYSKUSJA}

Według Olszaka (2017) w przełomie Dunajca tempo wypiętrzania obszaru wynosiło średnio w ciagu ostatnich 100 tys. lat 0,64 mm/rok, a w dolinie Ochotnicy 0,55 mm/rok. Prostolinijny przebieg frontów górskich Pasma Lubania może jednak wskazywać na jeszcze szybsze tempo tego procesu.

Fronty górskie o wskaźniku $\mathrm{S}_{\mathrm{mf}}>1,4$ były wiązane $\mathrm{z}$ tempem wypiętrzania $0,4-0,5 \mathrm{~mm} /$ rok (Rockwell $\mathrm{i}$ in., 
Wskaźnik krętości frontu masywu górskiego $\left(\mathrm{S}_{\mathrm{mf}}\right)$

Mountain front sinuosity in-dex $\left(S_{m f}\right)$
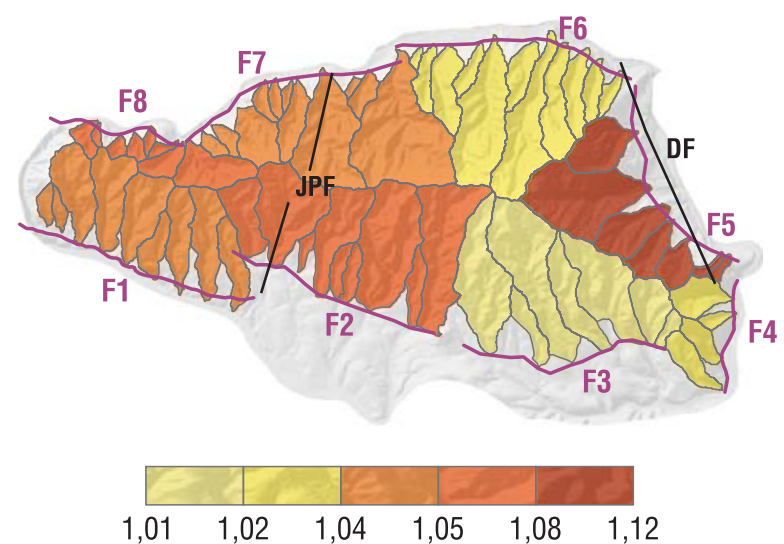

C Wskaźnik długość - spadek rzeki (SL)

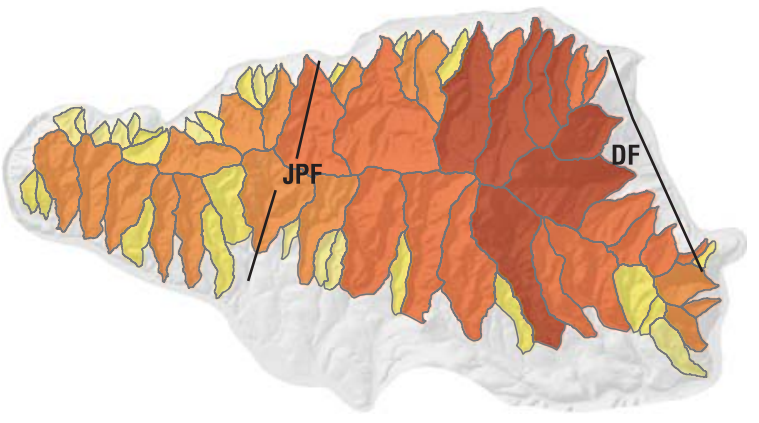

$\begin{array}{llllll}60,3 & 95,7 & 122,7 & 153,2 & 199,8 & 270,8\end{array}$

- Wskaźnik szerokości dna - wysokości zboczy doliny $\left(V_{f}\right)$

Valley floor width - valley height ratio $\left(V_{f}\right)$
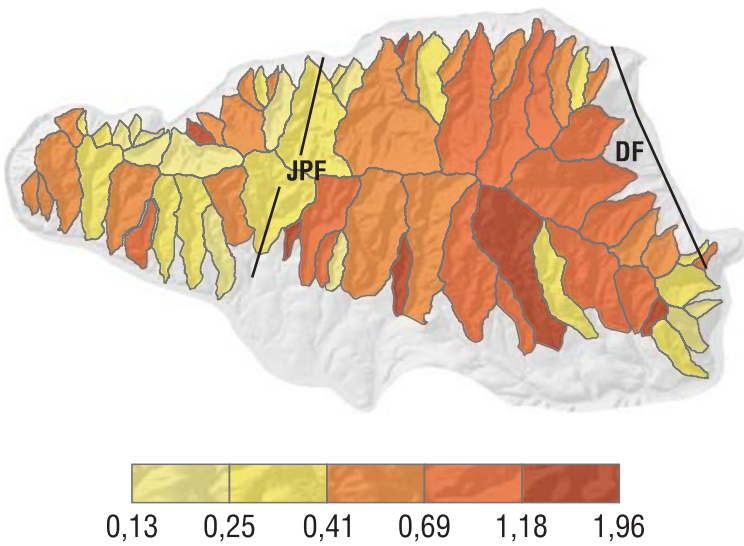

F1-F8 fronty masywu górskiego considered mountain fronts
Wskaźnik kształtu zlewni (Bs)

Drainage basin shape ratio $(B s)$
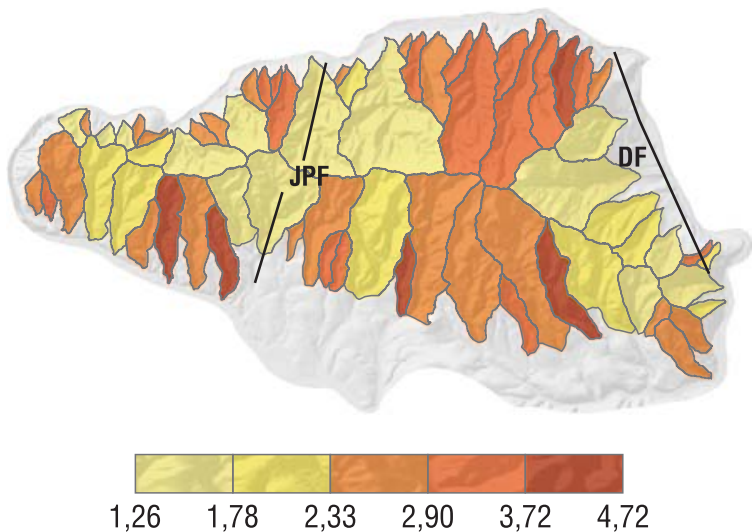

Całka hipsometryczna (Hi)
Hypsometric integral (Hi)
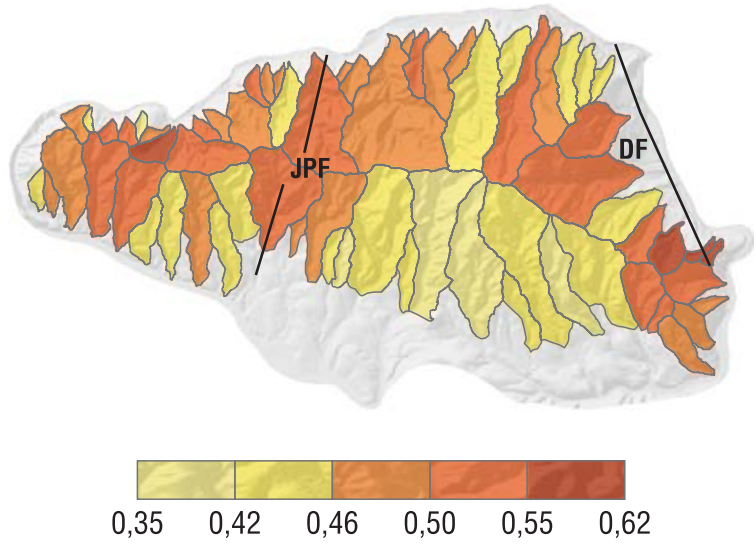

Eskaźnik asymetrii zlewni (AF)

Asymmetry factor (AF)
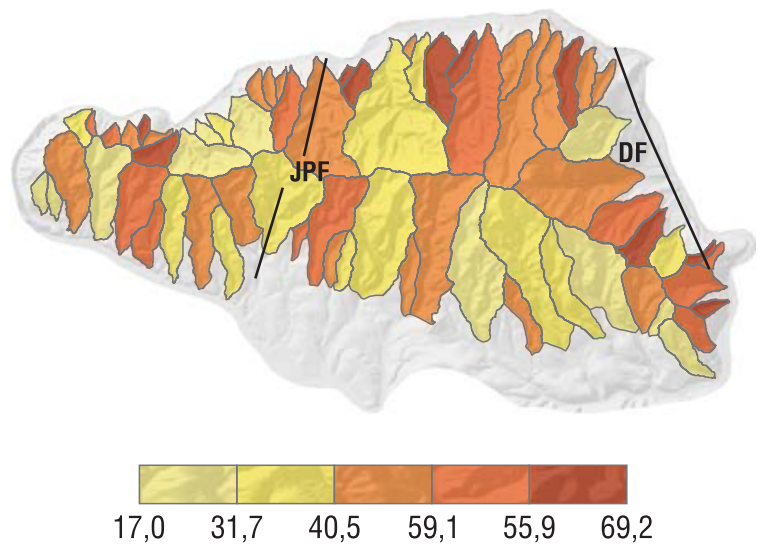

uskok Dunajca Dunajec Fault

JPF uskok Jurkowski Potok-Piekiełko Jurkowski Potok-Piekiełko Fault

Ryc. 2. Wartości analizowanych wskaźników morfometrycznych w zlewniach na obszarze Pasma Lubania

Fig. 2. Distribution of selected geomorphic indices in the Lubań Range basin 
1985), a nawet 1,0-5,0 mm/rok (Bull i in., 1978). Obecność trójkątnych lic progów uskokowych jedynie w południowej części przełomu Dunajca (wzdłuż frontów F4 oraz F5), a także wysokie wartości wskaźników Hi, Af i $\mathrm{V}_{\mathrm{f}}$, wyliczonych dla tego obszaru, potwierdzają sugerowane przez Olszaka (2017) zróżnicowane tempo wypiętrzania w przełomie Dunajca.

Niższe wartości wskaźnika Iat w zlewniach w strefie przełomu Dunajca są skutkiem obecności w tym rejonie kolistych, symetrycznych zlewni o szerokich dnach dolin (wskaźniki $\mathrm{B}_{\mathrm{s}}, \mathrm{Af}, \mathrm{V}_{\mathrm{f}}$; ryc. 2). Obecność takich zlewni jest uznawana $\mathrm{w}$ literaturze za przejaw słabszej aktywności tektonicznej (Burbank, Anderson, 2011; Różycka, 2015). W świetle dotychczasowych wyników badań, wskazujących na znaczne tempo wypiętrzania tego obszaru (Zuchiewicz, 1984, 1999; Olszak, Adamiec, 2016; Olszak, 2017), można przypuszczać, że kształt zlewni oraz szerokość den dolin są uwarunkowane nie tyle aktywnością tektoniczną, co mniejszą odpornością skał podłoża (np. formacji szczawnickiej). Symetryczny kształt tych zlewni nie musi zatem wskazywać na ich słaba aktywność tektoniczną, lecz może być związany z podnoszeniem obszaru w kierunku zbieżnym z główną osią drenażu. Znaczne wysokości względne, obserwowane w przełomie Dunajca $(827 \mathrm{~m})$, wskazują być może na izostatyczne dźwiganie wiszącego skrzydła uskoku normalnego, na którym znajduje się szczyt Lubania, podobnie jak dzieje się to w rejonie Babiej Góry czy Góry Cergowej (Jankowski, Margielewski, 2014).

Wzdłuż frontów górskich okalających Pasmo Lubania występują liczne trójkątne oraz trapezoidalne lica progów uskokowych (ryc. 3), których obecność jest zazwyczaj wiązana $\mathrm{z}$ dźwiganiem obszaru wzdłuż reaktywowanych uskoków normalnych (Burbank, Anderson, 2011). Formy te towarzyszą również elewacjom przyuskokowym w strefach uskoków przesuwczych czy też zrzutowo-przesuwczych (Vernicke, Axen, 1988). Piętrowe ułożenie lic (widoczne przede wszystkim wzdłuż frontu F1; ryc. 3) oraz ich różny stopień zerodowania mogą wskazywać na kilka epizodów wypiętrzania oraz różne tempo tego procesu wzdłuż poszczególnych krawędzi pasma (por. Bull, McFadden, 1977). Obecność lic wzdłuż reaktywowanych tektonicznie uskoków przesuwczych, zorientowanych SSE-NNW i SSW-NNE, wskazuje na zróżnicowane tempo wypiętrzania w obrębie Pasma Lubania. Najlepiej zachowane lica znajdują się wzdłuż frontów F7 i F8, okalających obszar

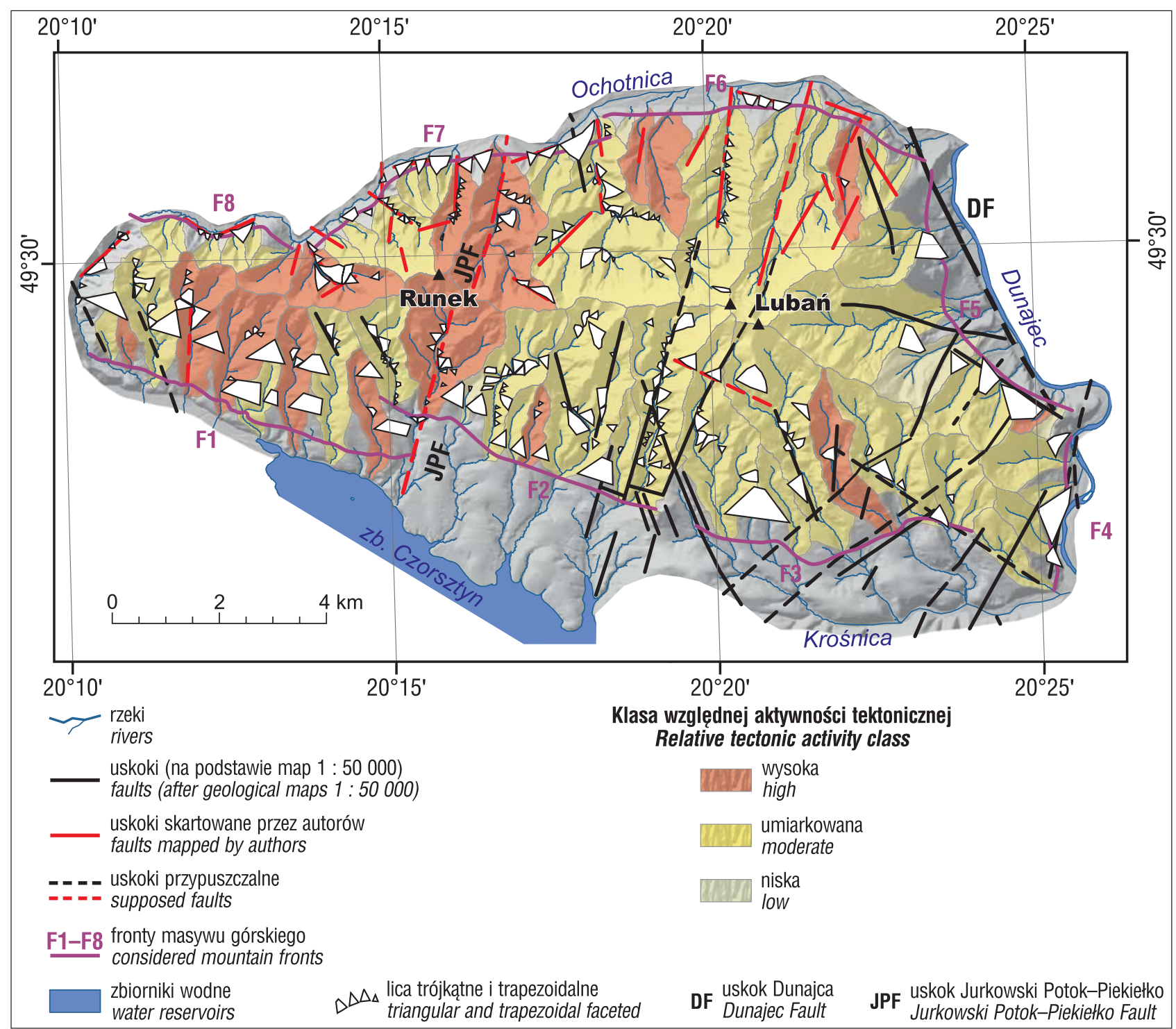

Ryc. 3. Rozmieszczenie klas wskaźnika względnej aktywności tektonicznej (Iat) na obszarze Pasma Lubania

Fig. 3. Distribution of relative tectonic activity classes (Iat) in the Lubań Range 

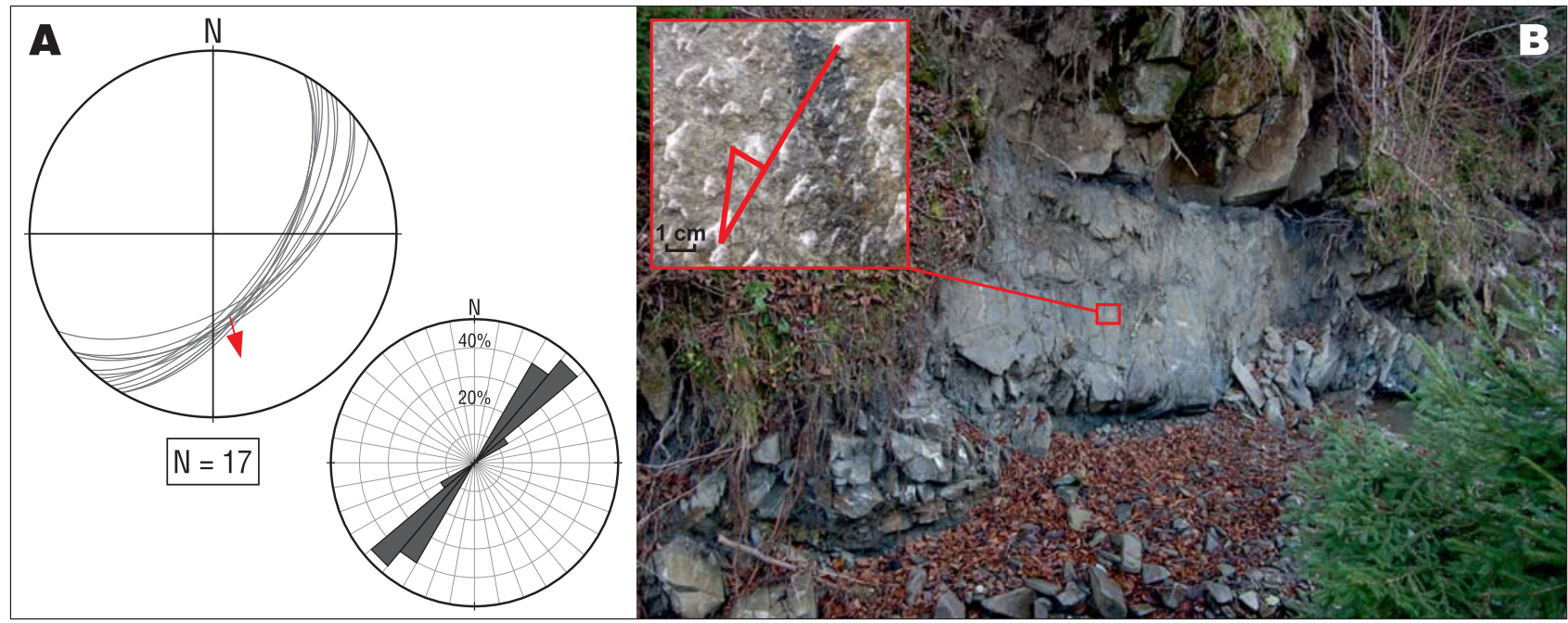

Ryc. 4A - Orientacja przestrzenna uskoku Jurkowski Potok-Piekiełko na diagramie kołowym i rozetowym - czerwoną strzałką zaznaczono kierunek przemieszczenia. B - Powierzchnia uskoku Jurkowski Potok-Piekiełko z widocznym lustrem tektonicznym. Strzałką oznaczono ruch skrzydła zrzuconego. Fot. K. Buczek

Fig. 4A - Spatial orientation of the Jurkowski Potok-Piekiełko Fault on the great circle and rose diagram - red arrow indicates the direction of movement. B - Fault surface with visible slickenslides, and the arrow indicates the movement of hanging wall. Photo by K. Buczek

badań od północy, co koreluje z większym udziałem zlewni znajdujących się w I klasie Iat (ryc. 3). Na wysoką względną aktywność tektoniczną wzdłuż frontu górskiego F1 wskazują m.in.: znaczne wydłużenie oraz asymetria zlewni, a także głębokie wcięcie cieków. Wzdłuż tego frontu występują pasy wysokich lic, lecz słabo nachylonych, których kształt prawdopodobnie jest związany z mniejszą odpornością skał (Bull, McFadden, 1977).

\section{WNIOSKI}

Wartości syntetycznego wskaźnika względnej aktywności tektonicznej Iat wskazują na umiarkowaną aktywność tektoniczną większości (ok. 72\%) obszaru Pasma Lubania (zgodnie z kryteriami przyjętymi za El Hamdounim i in., 2008). Wyjątkiem jest zachodnia część pasma, w której wskaźnik ten sugeruje wysoką względną aktywność tektoniczną (ryc. 3). Zlewnie usytuowane wzdłuż frontów górskich w antecedentnym przełomie Dunajca (F5) oraz dolnym odcinku Ochotnicy (F6) należą w większości do II klasy Iat, której El Hamdouni i in. (2008) przypisują tempo dźwigania od 0,5 do $0,05 \mathrm{~mm} / \mathrm{rok}$. Tempo to jest zbliżone do dotychczas wzmiankowanego w literaturze tempa wypiętrzania się obszaru czy też utożsamianego z nim wcinania się Dunajca oraz potoku Ochotnica (Zuchiewicz, 1984; Olszak, 2009; Olszak, Adamiec, 2016; Olszak, 2017).

$\mathrm{Na}$ obszarach fliszowych przydatność wskaźnika Iat może niekiedy być ograniczona ze względu na znaczne zróżnicowanie odporności skał (np. formacji szczawnickiej), jednak oszacowane za jego pomocą tempo wypiętrzania wschodniej części Pasma Lubania jest zbliżone do oszacowanego na podstawie rozcięcia erozyjnego cokołów skalnych tarasów rzecznych (Zuchiewicz, 1984; Olszak, Adamiec, 2016; Olszak, 2017).

Analiza cząstkowych wskaźników morfometrycznych $\left(\mathrm{S}_{\mathrm{mf}}, \mathrm{V}_{\mathrm{f}}, \mathrm{Af}, \mathrm{SL}, \mathrm{B}_{\mathrm{s}}, \mathrm{Hi}\right)$, chrakteryzujących badane zlewnie, nie jest tak jednoznaczna w kwestii oceny aktywności tektonicznej Pasma Lubania. Wartości wskaźników SL oraz Hi, szczególnie określające zlewnie we wschodniej części Pasma Lubania, wskazują na wysoką względną aktywność tektoniczną, podczas gdy inne wskaźniki, np. $\mathrm{V}_{\mathrm{f}}$ i $\mathrm{B}_{\mathrm{s}}$, sugerują słabszą aktywność tektoniczną badanego obszaru (ryc. 2). Niezgodność ta może wynikać $\mathrm{z}$ różnic $\mathrm{w}$ odporności skał podłoża na wietrzenie i erozję, które w istotny sposób wpływają na procesy denudacyjne transformujące zlewnie.

Wartości większości cząstkowych wskaźników morfometrycznych potwierdzają jednak szybsze tempo dźwigania zachodniej części Pasma Lubania (ryc. 2). Obszar ten jest prawdopodobnie silnie wypiętrzany tektonicznie wzdłuż północnej krawędzi (fronty F8 i F7).

Z kolei na wypiętrzanie Pasma Lubania wzdłuż uskoku Jurkowski Potok-Piekiełko (ryc. 4), reaktywowanego jako uskok normalny, wskazuje pozycja hipsometryczna szczytu Runka (1005 m n.p.m.). Szczyt ten jest wyniesiony ok. 50 m ponad wierzchowinę Pasma Lubania, a ponieważ znajduje się w wiszącym skrzydle uskoku, jego pozycja może być związana z wypiętrzaniem przyuskokowym (Vernicke, Axen, 1988).

Znaczne wcięcie cieków (wskaźnik $\mathrm{V}_{\mathrm{f}}$ ) oraz wydłużenie zlewni odwadniających południowe stoki (wskaźnik $\mathrm{B}_{\mathrm{s}}$ ) zachodniej części Pasma Lubania mogą wynikać z obniżania się ich bazy erozyjnej na skutek aktywnej subsydencji Kotliny Orawsko-Nowotarskiej.

Wyniki badań wskazują również na znaczne ograniczenie użyteczności wskaźnika asymetrii zlewni (Af) jako części składowej wskaźnika Iat. Wskaźnik Af jest czuły na pochylanie tektoniczne jedynie w kierunku prostopadłym do przebiegu głównej osi drenażu. W przypadku kierunku pochylenia zgodnego z biegiem cieku wartości wskaźnika Af będą sugerować małą aktywność tektoniczną zlewni, wpływając finalnie na zmianę klasy względnej aktywności tektonicznej Iat. Autorzy proponują, aby wskaźnik asymetrii zlewni traktować jedynie pomocniczo, w celu określania możliwych tendencji do pochylania tektonicznego.

Autorzy składają serdeczne podziękowania Recenzentom za liczne uwagi, które wpłynęły na ostateczną treść artykułu. Praca powstała w ramach badań statutowych Instytutu Ochrony Przyrody PAN (zadanie $n r$ VI/2). 


\section{LITERATURA}

ALIPOOR R., POORKERMANI M., ZARE M., EL HAMDOUNI R., 2011 - Active tectonic assessment around Rudbar Lorestan dam site, High Zagros Belt (SW of Iran). Geomorphology, 128: 1-14. ARIAN M., ARAM Z. 2014 - Relative tectonic activity classification in Kermanshah area, west Iran. Solid. Earth Discuss., 5: 2097-2141. AZAÑÓN J.M., PÉREZ-PEÑA J.V., GIACONIA F., BOOTH-REA G., MARTÍNEZ-MARTÍNEZ J.M., RODRÍGUEZ-PECES M.J. 2012 Active tectonics in the central and eastern Betic Cordillera through morphotectonic analysis: the case of Sierra Nevada and Sierra Alhamilla. J. Iberian Geol., 38 (1): 225-238.

AZOR A., KELLER E.A., YEATS R.S. 2002 - Geomorphic indicators of active fold growth: South Mountain-Oak Ridge Ventura basin, southern California. Geol. Soc. Am. Bull., 114: 745-753.

BAGHA N., ARIAN M., GHORASHI M., POURKERMANI M., EI HAMDOUNI R., SOLGI A. 2014 - Evaluation of relative tectonic activity in the Tehran basin, central Alborz, northern Iran. Geomorphology, 213: 66-87.

BAHRAMI S. 2013 - Analyzing the drainage system anomaly of Zagros basins: Implications for active tectonics. Tectonophysics, 608: 914-928. BRZEZIŃSKA-WÓJCIK T. 2013 - Morfotektonika w annopolsko-lwowskim segmencie pasa wyżynnego w świetle analizy cyfrowego modelu wysokościowego oraz wskaźników morfometrycznych. Wyd. UMCS, Lublin: 397.

BUCAŁA A., MARGIELEWSKI W., STARKEL L., BUCZEK K., ZERNITSKAYA V. 2014 - The reflection of human activity in the sediments of Iwankowskie Lake from Subatlantic Phase (Polish Outer Carpathians). Geochronometria, 41 (4): 377-391.

BUCZEK K. 2016 - The human impact on evolution of the landslide lake. Case Study of Lake Pucołowski Stawek in the Gorce Mts. Geogr. Stud., 142: 41-56.

BULL W.B. 1978 - Geomorphic Tectonic Classes of the South Front of the San Gabriel Mountains, California. U.S. Geological Survey Contract Report, 14-08-001-G-394. Office of Earthquakes, Volcanoes and Engineering, Menlo Park, CA.

BULL W.B., MCFADDEN L.D. 1977 - Tectonic geomorphology north and south of the Garlock fault, California. [W:] Doehring D.O. (red.) Geomorphology in Arid Regions. Proceedings of the Eighth Annual Geomorphology Symposium. State University of New York, Binghamton: 115-138.

BURBANK D.W., ANDERSON R.S. 2011 - Tectonic Geomorphology ( $2^{\text {nd }}$ ed.). Wiley-Blackwell.

BURTAN J., PAUL Z., WATYCHA L. 1976 - Szczegółowa mapa geologiczna Polski 1:50 000, ark. Mszana Górna, Wyd. Geol., Warszawa.

BURTAN J., PAUL Z., WATYCHA L. 1978 - Objaśnienia do szczegółowej mapy geologicznej Polski 1:50 000, ark. Mszana Górna, Wyd. Geol., Warszawa: 68.

CHABUDZIŃSKI Ł., BRZEZIŃSKA-WÓJCIK T. 2013 - Zastosowanie ArcNEO do oceny przejawów neotektoniki na przykładzie zlewni górnego Wieprza (Roztocze, środkowo-wschodnia Polska). Landform Analysis, 24: 11-22.

CHANG Z., SUN W., WANG J. 2015 - Assessment of the relative tectonic activity in the Bailongjiang Basin: insights from DEM-derived geomorphic indices. Environ. Earth Scien., 74: 5143-5153.

DEHBOZORGI M., POURKERMANI M., ARIAN M., MATKAN A., MOTAMEDI H., HOSSEINIASL A. 2010 - Quantitative analysis of relative tectonic activity in the Sarvestan area, central Zagros, Iran. Geomorphology, 121: 329-341.

EHSANI J., ARIAN M. 2015 - Quantitative analysis of relative tectonic activity in the Jarahi-Hendijan basin area, Zagros, Iran. Geosciences J., 19 (4): 751-765.

EL-HAMDOUNI R., IRIGARAY C., FERNÁNDEZ T., CHACÓN J., KELLER E.A. 2008 - Assessment of relative active tectonics, southwes border of the Sierra Nevada (southern Spain). Geomorphology, 96: 150-173.

FORMA A., ZUCHIEWICZ W. 2002 - Morphotectonics of the Gorce Mountains, Western Outer Carpathians. Fol. Quater., 73: 69-78.

HACK J.T. 1973 - Stream-profile analysis and stream-gradient index. J. Res. U.S. Geol. Sur., 1: 421-429.

HARE P.W., GARDNER T.W. 1985 - Geomorphic indicators of vertical neotectonism along converging plate margins, Nicoya Peninsula, Costa Rica. [W:] Tectonic Geomorphology (red.), Morisawa M. and Hack J.T., Proceedings of the $15^{\text {th }}$ Geomorphology Symposium. Birmingham, Allen and Unwinr, Boston: 76-104.

JANKOWSKI L., MARGIELEWSKI W. 2014 - Strukturalne uwarunkowania rozwoju rzeźby Karpat zewnętrznych - nowe spojrzenie. Prz. Geol., 62: 29-35.
KELLER E.A., PINTER N. 2002 - Active Tectonics: Earthquakes, Uplift, and Landscape. Prentice Hall, New Jersey.

KONDRACKI J. 2000 - Geografia regionalna Polski. Wyd. Nauk. PWN, Warszawa.

KONON A. 2001 - Tectonics of the Beskid Wyspowy Mountains (Outer Carpathians, Poland). Geol. Quart., 45 (2): 179-204.

KSIAŻKIEWICZ M. 1972 - Budowa geologiczna Polski, 4, Tektonika tom 3, Karpaty. Inst. Geol. Warszawa.

KULKA A., RACZKOWSKI W., ŻYTKO K., GUCIK S., PAUL Z. 1985 - Szczegółowa mapa geologiczna Polski 1:50 000, ark. Szczawnica-Krościenko, Wyd. Geol., Warszawa.

KULKA A., RACZKOWSKI W., ŻYTKO K., GUCIK S., PAUL Z. 1991 - Objaśnienia do szczegółowej mapy geologicznej Polski 1:50 000, arkusz 1050 Szczawnica-Krościenko, Wyd. Geol., Warszawa: 93.

MAKOWSKA A., JAROSZEWSKI W. 1987 - O współczesnych ruchach pionowych w Tatrach i na Podhalu. Prz. Geol., 35 (10): 506-512. MASTELLA L. 1988 - Structure and evolution of Mszana Dolna tectonic window, Outer Carpathians, Poland. Ann. Soc. Geol. Pol., 58 (1-2): 53-173

MIGOŃ P. 2006 - Geomorfologia. PWN Warszawa

NTOKOS D., LYKOUDI E., RONDOYANNI T. 2016 - Geomorphic analysis in areas of low-rate neotectonic deformation: South Epirus (Greece) as a case study. Geomorphology, 263: 156-169.

OLSZAK J. 2009 - Evidence for differential crustal uplift between neighbouring Kamienica and Ochotnica River valleys in the Polish Western Outer Carpathians. Ann. Soc. Geol. Pol., 79: 187-193.

OLSZAK J. 2017 - Late Pleistocene dip-slip faulting along the Dunajec Fault, West Carpathians: Insights from alluvial sediments. Geomorphology, 295: 749-757.

OLSZAK J., ADAMIEC G. 2016 - OSL-based chronostratigraphy of river terraces in mountainous areas, Dunajec basin, West Carpathians: a revision of the climatostratigraphical approach. Boreas, 45: 483-493.

PAUL Z. 1978 - Szczegółowa mapa geologiczna Polski 1:50 000, ark. Łącko, Wyd. Geol., Warszawa.

PAUL Z. 1980 - Objaśnienia do szczegółowej mapy geologicznej Polski 1:50 000, ark. Łącko. Wyd. Geol., Warszawa.

PŁACZKOWSKA E. 2014 - Geological aspects of headwater catchments development in the Lubań Range (the Outer Carpathians, Poland). Zeitschr. Geomorph., 58 (4): 525-537.

RAMÍREZ-HERRERA M.T. 1998 - Geomorphic assessment of active tectonics in the Acambay Graben, Mexican volcanic belt. Earth Surface Processes and Landforms, 23: 317-332.

ROCKWELL T.K., KELLER E.A., JOHNSON D.L. 1985 - Tectonic geomorphology of alluvial fans and mountain fronts near Ventura, California. [W:] Morisawa M. (red.), Tectonic Geomorphology. Proceedings of the $15^{\text {th }}$ Annual Geomorphology Symposium. Allen and Unwin Publishers, Boston, MA: 183-207.

RÓŻYCKA M. 2015 - Wskaźniki morfometryczne w geomorfologii tektonicznej. Landform Analysis, 30: 20-30.

SILVA P.G., GOY J.L., ZAZO C., BARDAJM T. 2003 - Fault generated mountain fronts in Southeast Spain: geomorphologic assessment of tectonic and earthquake activity. Gemorphology, 250: 203-226.

STRAHLER A.N. 1952 - Hypsometric (area-altitude) analysis of erosional topography. Geol. Soc. Am. Bull., 63: 1117-1142.

WATYCHA L. 1972 - Szczegółowa mapa geologiczna Polski 1:50 000, ark. Nowy Targ, Wyd. Geol., Warszawa.

WATYCHA L. 1976 - Objaśnienia do szczegółowej mapy geologicznej Polski 1:50 000, ark. Nowy Targ, Wyd. Geol., Warszawa.

WERNICKE B., AXEN G.J. 1988 - On the role of isostasy in the evolution of normal fault systems. Geology, 16: 848-851.

ZUCHIEWICZ W. 1978 - Czwartorzędowe ruchy tektoniczne, a rzeźba przełomu Dunajca przez Beskid Sądecki. Rocz. Pol. Tow. Geol., 48: $517-532$.

ZUCHIEWICZ W. 1984 - The Late Neogene-Quaternary tectonic mobility of the Polish West Carpathians. A case study of the Dunajec drainage basin. Ann. Soc. Geol. Polon., 54: 133-189.

ZUCHIEWICZ W. 1999 - The varied rate of river erosion in the Polish Outer Carpathians: the young tectonic movements ratio? Prz. Geol., 47 (9): 854-858.

ZUCHIEWICZ W. 2010 - Neotektonika Karpat polskich i zapadliska przedkarpackiego. Wyd. AGH, Kraków: 234.

ZUCHIEWICZ W. 2011 - Pleistocene tectonic activity of the Polish Western Carpathians: insights from fluvial terraces. Acta Geodyn. Geomat., 8: 197-224.

ŻYTKO K. 1963 - Wyniki badań okolic Krościenka nad Dunajcem. Kwart. Geol., 7 (4): 724-725.

Praca wpłynęła do redakcji 3.10.2018 r.

Akceptowano do druku 15.02.2019 r. 